\title{
CLINICAL ANKLE INVOLVEMENT AND ULTRASOUND SYNOVIAL HYPERTROPHY ARE SIGNIFICANT PREDICTORS OF DAS28-DEFINED RHEUMATOID ARTHRITIS DISEASE ACTIVITY
}

\author{
Luminița Enache ${ }^{1}$, Claudiu C. Popescu ${ }^{1,2}$, Cătălin Codreanu ${ }^{1,2}$, Maria Șuța $^{3}$ \\ "Dr. Ion Stoia" Clinical Centre of Rheumatic Diseases (Bucharest) \\ "2Carol Davila" University of Medicine and Pharmacy (Bucharest) \\ 3"Ovidius" University of Constanța, Faculty of Medicine \\ Corresponding author: Claudiu C. POPESCU \\ $5^{\text {th }}$ Thomas Masaryk street, Bucharest, Romania, district 2, postal code 020983, \\ email: claudiu.popescu@reumatologiedrstoia.ro
}

\begin{abstract}
Objective. The study aimed to investigate the relationship between ankle involvement and disease activity in rheumatoid arthritis (RA), from clinical and ultrasound perspectives.
\end{abstract}

Methods. RA patients were recruited in 2018 in the random order of presentation from the out-patient clinic. On the same day of inclusion, all patients underwent clinical examination, laboratory tests (inflammatory markers), ankle ultrasound and patient-reported outcomes.

Results. The study included 183 patients with established RA, mostly women (86.3\%), with mean age of 57.3 years. Clinical examination revealed 101 (55.2\%) patients with at least one tender ankle and 56 (30.6\%) patients with at least one swollen ankle. Regression analysis revealed that both clinically tender and swollen ankles were 2.8 and respectively 3.4 times more likely to reveal ultrasound ankle joint synovial hypertrophy (SH). The presence of ankle $\mathrm{SH}$ was associated with higher disease activity: for example, compared to patients without ankle $\mathrm{SH}$, patients with ultrasound-detected $\mathrm{SH}$ in any ankle joint had significantly higher median DAS28CRP (4.60 compared to $2.73, p<0.001$ ). Power Doppler (PD) activity of ankle SH produced similar results: $P D$ signal presence $(p<0.001)$ and $P D$ grade $(p=0.009)$ were associated with higher median DAS28CRP. Ankle joint involvement had an independent effect on DAS28CRP-defined disease activity: for example, the absence of ankle SH independently and significantly decreased DAS28CRP with 0.985 points $(p<0.001)$.

Conclusion. Clinical ankle involvement and ultrasound-detected ankle SH have a directly proportional relationship with disease activity in $R A$.

Keywords: rheumatoid arthritis, ankle, ultrasound. 


\section{INTERNAL}

\section{Original papers}

\section{Rezumat}

Obiectiv. Studiul a urmărit să investigheze relația dintre afectarea gleznei și activitatea bolii în poliartrita reumatoidă (PR), din perspectiva clinică și ecografică.

Metode. Pacienții cu PR au fost recrutați în 2018, în ordinea aleatorie de prezentare din clinica ambulatorie. În ziua includerii, toți pacienții au fost examinați clinic, au efectuat teste de laborator (reactanți de fază acută), ecografie de glezne și au completat chestionarele de raportare a calității vieții și a evaluării subiective a activității bolii.

Rezultate. Studiul a inclus 183 de pacienți cu PR, majoritatea femei (86,3\%), cu vârsta medie de 57,3 ani. Examinarea clinică a evidențiat 101 (55,2\%) pacienți cu cel puțin o gleznă dureroasă și $56(30,6 \%)$ de pacienți cu cel puțin o gleznă tumefiată. Analiza de regresie a arătat că gleznele dureroase și gleznele tumefiate au crescut de 2,8 ori, respectiv de 3,4 ori riscul de detecție ecografică a hipertrofiei sinoviale (HS) în glezne. Prezența HS la nivelul gleznei a fost asociată cu o activitate mai mare a bolii: de exemplu, comparativ cu pacienții fără HS la nivelul gleznei, cei cu HS detectată ecografic în oricare dintre articulatiile gleznei, aveau DAS28 ${ }_{C R P}$ semnificativ mai mare $(4,60$ comparativ cu 2,73; $p<0,001)$. Prezența semnalului power Doppler (PD) in interiorul articulațiilor gleznei, la nivelul HS, a produs rezultate similare: prezența semnalului $P D(p<0,001)$ și gradul semnalului $P D(p=0,009)$ au fost asociate cu valori DAS28 $8_{C R P}$ mai mari. Afectarea gleznei a avut un efect independent asupra activității bolii definite de DAS28 ${ }_{C R P}$ : de exemplu, absența HS la nivelul gleznei a scăzut în mod independent și semnificativ DAS28 ${ }_{C R P} c U 0,985$ de puncte $(p<0,001)$.

Concluzie. Afectarea clinică a gleznei și HS detectată ecografic în interiorul articulațiilor gleznei au o relație direct proporțională cu activitatea bolii la pacienții cu PR.

Cuvinte cheie: poliartrita reumatoidă, gleznă, ecografie 


\section{Introduction}

Clinicians often encounter in clinical practice patients with rheumatoid arthritis (RA) whose disease onset started with ankle involvement or, who have persistent ankle involvement despite achieving disease remission defined by composite scores (e.g. DAS28 ${ }^{(1)}$ ). The first observation was recently confirmed in a large national cohort, in which $43.8 \%$ of RA patients reported that their disease started with ankle or foot symptoms ${ }^{(2)}$. The second observation was acknowledged by the European League against Rheumatism (EULAR) taskforce who recommended including ankles in order to define RA Boolean remission ${ }^{(3)}$. Clinical evaluation of ankle joints can be difficult due to their complex anatomy and multiple possible confounders which can decrease the accuracy for the detection of RA-related involvement (for example obesity). Complementing clinical examination, musculoskeletal ultrasound is useful for a more objective evaluation of RA ankle involvement ${ }^{(4)}$.

Podiatrists have observed that the clinicallyjustified recommendation to evaluate ankles in RA management, although present in many practical guidelines, is supported by few and low quality literature evidence ${ }^{(5)}$. The rarity of ankle studies in RA is certain, but a more important problem is that some of this evidence is contradictory. Using both clinical examination and US, Elsaman et al. (6) $^{(6)}$ served that RA patients with ultrasound-defined ankle synovitis had significantly higher DAS28, but Gutierrez et $a l^{(7)}$ reported no significant association of ankle ultrasound findings with DAS28.

\section{Objective}

In the above context, we aimed to investigate the relationship of ankle involvement and disease activity in RA, from clinical and ultrasound perspectives. For the purpose of this article, we will limit the analysis to clinical examination and ultrasound-defined synovial hypertrophy (SH) and power Doppler detection, following that tendon involvement related to disease activity and ankle involvement in RA remission be reported in subsequent articles.

\section{Methods}

\section{Patient selection}

RA patients were recruited in 2018 in the random order of presentation to the outpatient clinic from an academic hospital (Clinical Centre for Rheumatic Diseases, Bucharest, Romania). Study inclusion required fulfilment of the 2010 American College of Rheumatology (ACR)/EULAR classification criteria of $R A^{(8)}$ and age above 18 years. Exclusion criteria consisted of history or current ankle deformity/surgery, local complex regional pain syndrome, fibromyalgia, pregnancy, injectable glucocorticoids (pulsetherapy, intramuscular, intra-articular injections) in the month prior to study inclusion. Oral glucocorticoids ( $\leq 10 \mathrm{mg}$ prednisone equivalent) which were stable in the month prior to study inclusion were allowed. Similarly, stable doses of nonsteroidal anti-inflammatory drugs (NSAIDs) in the last week were allowed. The study was approved by the local ethics committee and all patients gave written informed consent prior to enrolment and any study procedures. On the same day of study inclusion, all patients underwent clinical examination, laboratory tests, ankle ultrasound and completed independently patient-reported outcomes: patient global assessment of general health (PtGA; on a $100 \mathrm{~mm}$ visual analogues scale) and health assessment questionnaire (HAQ). 


\section{INTERNAL}

\section{Original papers}

\section{Clinical and laboratory evaluation}

All clinical examinations were done by the same senior rheumatologist, blinded to laboratory and ultrasound results. Both ankles were examined by inspection, palpation and active movement at each compartment, looking for signs of inflammation (pain and/or swelling). Concomitant local pathology was also noted: hallux valgus, pes planus, chronic venous insufficiency. A clinical interview noted aspects of general medical history, RA history and current anti-rheumatic treatment. Obesity was defined as body mass index above $30 \mathrm{~kg} / \mathrm{m}^{2}$. Standard 28joint tender/swollen counts were performed and disease activity scores (DAS) were computed: DAS28 ${ }^{(1)}$ using C-reactive protein (CRP, which is better correlated with synovial inflammation than erythrocyte sedimentation rate - $\mathrm{ESR}^{(9)}$ ) and SDAl (simplified disease activity index $)^{(10)}$. Laboratory tests included CRP (normal $<5$ $\mathrm{mg} / \mathrm{dL}$ ), ESR (normal $<20 \mathrm{~mm} / \mathrm{h}$ ), rheumatoid factor (RF; normal $<30 \mathrm{IU} / \mathrm{mL}$ ) and anti-citrullinated protein antibodies (ACPA; normal < $20 \mathrm{IU} / \mathrm{mL}$ ).

\section{Ankle ultrasound}

Ankle ultrasound scans were performed and interpreted by a single rheumatologist with more than 7 years of experience in RA patients (Figure 1 ), on the same day as the clinical examination and blinded to its result. Using an Esaote MyLabTwice machine (12-18 $\mathrm{MHz}$ linear transducer), both ankles were scanned according to the EULARrecommended ankle technique(11). Ultrasound evaluation included tibiotalar joints (TTJ) with anterior and posterior recess, talonavicular joints (TNJ) and subtalar joints (STJ) from their lateral, medial and posterior aspects. First, ankles were scanned in grey scale, followed by power Doppler (PD) technique, using constant settings (gain just below the noise level, $750 \mathrm{~Hz}$ pulse repetition frequency, 8-10 MHz Doppler frequency, low wall filter). Joint synovial hypertrophy ( $\mathrm{SH})$ was defined according to OMERACT recommendations ${ }^{(12)}$ and was quantified with the initial semi-quantitative scale developed by Szkudlarek et al. ${ }^{(13,14)}$, taking into account the latest EULAR-OMERACT recommendations ${ }^{(15)}$, verified on large joints. Multiple window ultrasound evaluation of the same joint recorded the highest SH/PD grade (0-3 corresponding to "absent", "minimal", "moderate" and "severe").

\section{Statistics}

Distribution normality was assessed using descriptive statistics, normality and stemand-leaf plots, and Kolmogorov-Smirnov tests. Differences of continuous variables (e.g. DAS28) among categorical variables (e.g. SH presence or grade) were tested with 


\begin{tabular}{|c|c|c|c|}
\hline women & $\begin{array}{l}158 \\
(86.3 \%)\end{array}$ & RF (IU/mL) & $75.3(0-1600)$ \\
\hline age $(y)$ & $57.3(12.5)$ & RF positive & $118(64.5 \%)$ \\
\hline disease duration (y) & $11.2(10.3)$ & ACPA (IU/mL) & $166.1(0-530)$ \\
\hline NSAIDs & $48(26.2 \%)$ & ACPA positive & $139(76.0 \%)$ \\
\hline glucocorticoids & $32(17.5 \%)$ & TJC28 & $4(0-25)$ \\
\hline csDMARDs & $\begin{array}{l}155 \\
(84.7 \%)\end{array}$ & $=1$ tender ankle & $101(55.2 \%)$ \\
\hline methotrexate & $88(48.1 \%)$ & $\mathrm{SJC28}$ & $1(0-24)$ \\
\hline$>1$ csDMARD & $17(9.3 \%)$ & $\begin{array}{l}=1 \text { swollen } \\
\text { ankle }\end{array}$ & $\begin{array}{l}56 \\
(30.61026+\%)\end{array}$ \\
\hline bDMARDs & $64(35.0 \%)$ & $\mathrm{ESR}(\mathrm{mm} / \mathrm{h})$ & $34(2-98)$ \\
\hline $\begin{array}{l}\text { bDMARD } \\
\text { monotherapy }\end{array}$ & $1(0.5 \%)$ & CRP (mg/L) & $9.2(0.2-196)$ \\
\hline T2DM & $17(9.3 \%)$ & PtGA (mm) & $42.6(25.9)$ \\
\hline hallux valgus & $58(31.7 \%)$ & PhGA (mm) & $31.5(22.8)$ \\
\hline $\mathrm{CVI}$ & $38(20.8 \%)$ & $\mathrm{DAS28}_{\mathrm{ESR}}$ & $4.4(1.7)$ \\
\hline rheumatoid foot & $18(9.8 \%)$ & DAS28 $8_{\text {CRP }}$ & $3.8(1.7)$ \\
\hline obesity & $4(2.2 \%)$ & SDAI & $18.3(15.7)$ \\
\hline pes planus & $4(2.2 \%)$ & HAQ & $1.5(0.8)$ \\
\hline fibromyalgia & $1(0.5 \%)$ & & \\
\hline \multicolumn{4}{|c|}{$\begin{array}{l}\text { notes: normally-distributed continuous variables are reported as "mean } \\
\text { (standard deviation)"; non-normally distributed continuous variables are } \\
\text { reported as "median (minimum-maximum)"; nominal variables are } \\
\text { reported as "count (percentage from sample)" }\end{array}$} \\
\hline \multicolumn{4}{|c|}{$\begin{array}{l}\text { abbreviations: ACPA - anti-citrullinated protein antibodies; b/cs/tDMARDs } \\
\text { - biologic/conventional synthetic/targeted disease-modifying anti- } \\
\text { rheumatic drugs; CRP - C-reactive protein; CVI - chronic venous } \\
\text { insufficiency; DAS - disease activity score; ESR - erythrocyte } \\
\text { sedimentation rate; HAQ - health assessment questionnaire; IU - } \\
\text { international units; NSAIDs - non-steroidal anti-inflammatory drugs; } \\
\text { Ph/tGA - physician/patient global assessment of disease activity; RF - } \\
\text { rheumatoid factor; SDAI - simplified disease activity index; S/TJC - } \\
\text { swollen/tender joint count; T2DM - type } 2 \text { diabetes mellitus; y - years. }\end{array}$} \\
\hline
\end{tabular}

Table 1. General characteristics of RA patients $(n=183)$ 


\section{INTERNAL MEDICINE}

Original papers

\begin{tabular}{|c|c|c|c|c|}
\hline \multicolumn{5}{|c|}{ 1. binary logistic regression models ${ }^{*}$ to predict SH presence in any ankle joint } \\
\hline & $\begin{array}{l}\text { Nagelkerke } \\
\mathrm{R}^{2}\end{array}$ & $\chi^{2}(13)^{\#}$ & OR $(95 \% \mathrm{Cl})$ & $\mathrm{p}$ \\
\hline $\begin{array}{l}\text { a) = } 1 \text { tender ankle } \\
\text { joint }\end{array}$ & 0.401 & 64.7 & $2.813(1.3,6.0)$ & 0.008 \\
\hline $\begin{array}{l}\text { b) = } 1 \text { swollen ankle } \\
\text { joint }\end{array}$ & 0.398 & 64.1 & $3.395(1.3,8.8)$ & 0.012 \\
\hline \multicolumn{5}{|c|}{ 2. multiple linear regression models" to predict DAS28 ${ }_{C R P}$} \\
\hline & adjusted $\mathrm{R}^{2}$ & $\begin{array}{l}\mathrm{F}(4, \\
180)^{\#}\end{array}$ & $\mathrm{~B}(95 \% \mathrm{Cl})$ & $p$ \\
\hline a) $\mathrm{SH}$ presence $=0$ & 0.483 & 43.1 & $-0.985(-1.3,-0.6)$ & $<0.001$ \\
\hline b) $\mathrm{SH}$ grade $=0$ & 0.494 & 36.1 & $-1.187(-1.6,-0.8)$ & $<0.001$ \\
\hline c) PD presence $=0$ & 0.442 & 36.1 & $-0.833(-1.3,-0.4)$ & $<0.001$ \\
\hline \multicolumn{5}{|c|}{$\begin{array}{l}\text { * all models included: gender, age (years), disease duration (years; significant in } \\
\text { models 2.a and 2.C), CRP (mg/L; only in models 1.a-b), PtGA (mm; significant in } \\
\text { models 1.a-b), HAQ (significant in models 2.a-c), seropositivity (RF or/and ACPA } \\
\text { positive), csDMARDs, bDMARDs (significant in models 2.a-c), glucocorticoids, } \\
\text { NSAIDs, ankle confounders (T2DM, hallux valgus, CVI, rheumatoid foot, obesity, } \\
\text { pes planus, fibromyalgia) and one clinical/ ultrasound ankle variable. } \\
\text { \# p }<0.001 .\end{array}$} \\
\hline \multicolumn{5}{|c|}{$\begin{array}{l}\text { ACPA - anti-citrullinated protein antibodies; b/csDMARDs - biologic/conventional } \\
\text { synthetic disease-modifying anti-rheumatic drugs; CI - confidence interval; CRP - } \\
\text { C-reactive protein; CVI - chronic venous insufficiency; DAS - disease activity score; } \\
\text { HAQ - health assessment questionnaire; NSAIDs - non-steroidal anti-inflammatory } \\
\text { drugs; OR - odds ratio; PD - power Doppler; PtGA - patient global assessment; RF - } \\
\text { rheumatoid factor; SH - synovial hypertrophy; T2DM - type } 2 \text { diabetes mellitus. }\end{array}$} \\
\hline
\end{tabular}

Table 2. Regression analysis 


\begin{tabular}{|c|c|c|c|c|}
\hline & \multicolumn{2}{|c|}{$\geq 1$ tender ankle } & \multicolumn{2}{|c|}{$\geq 1$ swollen ankle } \\
\hline & no $(n=82)$ & $\begin{array}{l}\text { yes } \\
(n=101)\end{array}$ & no $(n=82)$ & yes $(n=56)$ \\
\hline TJC28 & $3(7)$ & $8(8)^{*}$ & $2(7)$ & $5(9)^{*}$ \\
\hline SJC28 & $0(3)$ & $6(7)^{*}$ & $0(3)$ & $3(9)^{*}$ \\
\hline ESR $(\mathrm{mm} / \mathrm{h})$ & $30(34)$ & $42(34)^{\#}$ & $28(31)$ & $38(42)^{\pi}$ \\
\hline CRP (mg/L) & $5.5(11.9)$ & $23.9(30.1)^{*}$ & $4.3(13.8)$ & $14.9(50.4)^{*}$ \\
\hline PtGA $(\mathrm{mm})$ & $30(40)$ & $60(40)^{*}$ & $30(32)$ & $55(33)^{*}$ \\
\hline PhGA (mm) & $20(27)$ & $50(30)^{*}$ & $17(25)$ & $35(30)^{*}$ \\
\hline DAS28 $8_{\mathrm{ESR}}$ & $3.7(2.6)$ & $5.7(2.2)^{*}$ & $3.4(2.5)$ & $5.2(1.9)^{*}$ \\
\hline DAS28 ${ }_{\text {CRP }}$ & $3.0(2.5)$ & $5.3(2.2)^{*}$ & $2.6(2.4)$ & $4.5(1.9)^{*}$ \\
\hline SDAI & $10.0(15.3)$ & $30.4(22.4)^{*}$ & $7.3(16.0)$ & $20.4(22.3)^{*}$ \\
\hline HAQ & $1.4(1.6)$ & $2.0(1.3)^{\Phi}$ & $1.4(1.6)$ & $1.9(1.3)^{\ddagger}$ \\
\hline $\mathrm{RF}(\mathrm{IU} / \mathrm{mL})$ & $\begin{array}{l}57.1 \\
(146.3)\end{array}$ & $\begin{array}{l}95.5 \\
(179.4)^{\S}\end{array}$ & $\begin{array}{l}81.5 \\
(164.6)^{\S}\end{array}$ & $66.1(234.2)^{\S}$ \\
\hline ACPA (IU/mL) & $\begin{array}{l}169.4 \\
(209.2)\end{array}$ & $\begin{array}{l}164.9 \\
(182.3)^{\S}\end{array}$ & \begin{tabular}{l|}
164.0 \\
$(197.2)^{\S}$
\end{tabular} & $\begin{array}{l}175.6 \\
(193.9)^{\S}\end{array}$ \\
\hline \multicolumn{5}{|c|}{$\begin{array}{l}\text { Notes: categories are defined by the clinical examination finding of at } \\
\text { least one tender/swollen ankle (either the left or the right or both } \\
\text { ankles); values represent the median (interquartile range); p values } \\
\text { represent the significance levels of Mann-Whitney tests: } *<0.001 ; \# \\
0.002 ; \& 0.032 ; \uparrow 0.016 ; \ddagger 0.003 ; \S>0.08 \text {. }\end{array}$} \\
\hline \multicolumn{5}{|c|}{$\begin{array}{l}\text { Abbreviations: ACPA - anti-citrullinated protein antibodies; CRP - C- } \\
\text { reactive protein; DAS - disease activity score; ESR - erythrocyte } \\
\text { sedimentation rate; IU - international units; HAQ - health assessment } \\
\text { questionnaire; Ph/tGA - physician/patient global assessment of disease } \\
\text { activity; RA - rheumatoid arthritis; RF - rheumatoid factor; SDAI - } \\
\text { simplified disease activity index; S/TJC - swollen/tender joint count. }\end{array}$} \\
\hline
\end{tabular}

Table 3. RA activity indices, patient-reported outcomes and serology according to clinical ankle involvement $(n=183$ ) 


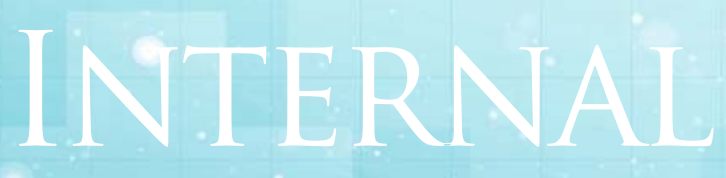

Original papers

non-parametric tests for independent variables (Mann-Whitney and Kruskal-Wallis tests respectively). Post-hoc Bonferoni pairwise comparisons of Kruskal-Wallis test results were done to identify significant differences among categories of multi-level nominal variables (e.g. SH grade). The ability of clinical findings (tender/swollen ankle) to predict ultrasound-defined ankle $\mathrm{SH}$ was studied using specificity, sensitivity and binary logistic regression and they were compared using the McNemar's test. DAS28 $8_{\text {CRP }}$ prediction was studied with standard multiple linear regression models built using SPSS automatic linear modelling with forward stepwise selection method, information criterion for entry/removal and $95 \%$ confidence interval. The statistical tests were considered significant if $p<0.05$ and were computed with IBM SPSS Statistics version 22.0 for Windows (Armonk, NY, IBM Corp.).

\section{Results}

The study included 183 patients with established RA (Table 1), mostly women (86.3\%), with a mean age of 57.3 (12.5) years. Clinical examination revealed 101 (55.2\%) patients with at least one tender ankle, of whom 69 had $\mathrm{SH}$ in at least one ankle joint (TTJ, TNJ and/or STJ), producing $71.1 \%$ sensitivity and $62.8 \%$ specificity for clinical examination to detect ultrasounddefined SH. Similarly, 56 (30.6\%) patients had at least one swollen ankle at clinical examination, of whom 46 had ankle $\mathrm{SH}$ on ultrasound $(47.4 \%$ sensitivity and $88.4 \%$ specificity). Regression analysis revealed that both clinically tender and swollen ankles were 2.8 and respectively 3.4 times more likely to reveal $\mathrm{SH}$ on ultrasound (Table 2). The difference between the ability of clinically tender and swollen ankles to predict $\mathrm{SH}$ presence on ultrasound was not significant (McNemar's $p=0.894$ ). Compared to patients without tender/swollen ankles, those with at least one tender/swollen ankle joint had significantly higher median disease activity indices (Table 3 ).

The presence of ankle $\mathrm{SH}$ was associated with higher disease activity (Table 4): for example, compared to patients without ankle $\mathrm{SH}$, patients with ultrasound-detected $\mathrm{SH}$ in any ankle joint (right, left, TTJ, TNJ and STJ) had significantly higher median DAS28 $8_{\text {CRP }}$ (4.60 compared to $2.73, p<0.001$ ). DAS28 $8_{\text {CRP }}$ values also increased proportionally and significantly with the number of ankles joint with SH (Figure 2, left panel): a patient with 4 ankle joints with $\mathrm{SH}$ (for example left $\mathrm{T}$ ), left TNJ, right TNJ and right STJ) had a significantly higher median DAS28 ${ }_{\text {CRP }}$ than a patient with 1 ankle joint SH (for example, right TNJ; $p=0.003$ ). The grade of ankle $\mathrm{SH}$ behaved similarly: Figure 2 (right panel) 


\begin{tabular}{|c|c|c|c|c|c|c|c|c|}
\hline & \multicolumn{2}{|c|}{$\mathrm{SH}$ in TTJ } & \multicolumn{2}{|c|}{ SH in TNJ } & \multicolumn{2}{|c|}{ SH in STJ } & \multicolumn{2}{|c|}{ SH in any } \\
\hline & $\begin{array}{c}\text { no } \\
(n=109)\end{array}$ & $\begin{array}{c}\text { yes } \\
(n=74)\end{array}$ & $\begin{array}{c}\text { no } \\
(n=131)\end{array}$ & $\begin{array}{c}\text { yes } \\
(n=52)\end{array}$ & $\begin{array}{c}\text { no } \\
(\mathrm{n}=126)\end{array}$ & $\begin{array}{c}\text { yes } \\
(n=57)\end{array}$ & $\begin{array}{c}\text { no } \\
(n=86)\end{array}$ & $\begin{array}{c}\text { yes } \\
(n=97)\end{array}$ \\
\hline TJC28 & 3 & $6 *$ & 3 & $7^{*}$ & 3 & 6 & 3 & $5^{*}$ \\
\hline SJC28 & 0 & $4^{*}$ & 1 & $4^{*}$ & 0 & $4^{*}$ & 0 & $3^{\#}$ \\
\hline ESR (mm/h) & 30 & $40^{*}$ & 32 & $40^{*}$ & 30 & $46^{*}$ & 30 & $39^{*}$ \\
\hline CRP (mg/L) & 5.2 & $19.6^{*}$ & 6.7 & $16.6^{\#}$ & 5.7 & $18.8^{*}$ & 4.1 & $15.7^{*}$ \\
\hline PtGA $(\mathrm{mm})$ & 30 & $60^{*}$ & 39 & $60^{*}$ & 30 & $60^{*}$ & 30 & $55^{*}$ \\
\hline PhGA (mm) & 20 & $40^{*}$ & 20 & $45^{*}$ & 20 & $45^{*}$ & 19 & $40^{*}$ \\
\hline $\mathrm{DAS28}_{\mathrm{ESR}}$ & 3.63 & $5.36^{*}$ & 4.37 & $5.46^{*}$ & 3.90 & $5.58^{*}$ & 3.59 & $5.21^{*}$ \\
\hline $\mathrm{DAS}_{\mathrm{CRP}}$ & 2.82 & $4.71^{*}$ & 3.63 & $4.88^{*}$ & 2.98 & $4.89^{*}$ & 2.73 & $4.60^{*}$ \\
\hline SDAI & 8.0 & $22.8^{*}$ & 12.0 & $26.2^{*}$ & 10.6 & $25.8^{*}$ & 7.6 & $20.7^{*}$ \\
\hline $\mathrm{HAQ}$ & 1.5 & $2.0^{\varangle}$ & 1.5 & $1.9^{\pi}$ & 1.4 & $2.0^{\pi}$ & 1.5 & $1.9^{\pi}$ \\
\hline
\end{tabular}

notes: joint categories include both ankles (e.g. a case was labeled "SH in TT)" if SH was present either in the right or left or both TTJs); values represent medians (interquartile range); $p$ values represent the significance levels of Mann-Whitney tests: $*=0.001 ; \#=0.01 ; \&<$ $0.05 ;$ १ $>0.06$.

abbreviations: CRP - C-reactive protein; DAS - disease activity score; ESR - erythrocyte sedimentation rate; HAQ - health assessment questionnaire; Ph/tGA - physician/patient global assessment of disease activity; SDAI - simplified disease activity index; SH - synovial

hypertrophy; STJ - subtalar joint; S/TJC - swollen/tender joint count; TNJ - talonavicular joint; TTJ - tibiotalar joint.

Table 4. Disease activity indices, patient-reported outcomes and serology according to SH presence in ankle joints

illustrates how patients with grade 3 ankle $\mathrm{SH}$ had significantly higher median DAS28 ${ }_{\mathrm{CRP}}$ compared to patients with grade 1 ankle $\mathrm{SH}$ $(p=0.013)$. PD activity of ankle SH produced similar results (Figure 3 ): PD signal presence $(p<0.001)$ and PD grade were associated with higher median DAS28 ${ }_{\text {CRP }}(p=0.009)$. The presence of ankle SH and its grades, and PD presence and its grades produced identical significant differences regarding all other disease activity measures reported in Table 3 ( $p<0.03$; data not shown). Ankle joint involvement had an independent effect on DAS28 $8_{C R P}$-defined disease activity: for example, taking into account all other significant covariates in the regression model (disease duration, HAQ, bDMARDs), the absence of ankle SH independently and significantly decreased DAS28 $8_{\text {CRP }}$ with 0.985 points ( $p<0.001$; Table 2 ).

\section{Discussion}

The observed association of ankle SH with higher disease activity confirms the results of Elsaman et al. ${ }^{(6)}$. In addition to their results, we observed further proof of causality: on one hand, not only the presence of $\mathrm{SH}$, but 


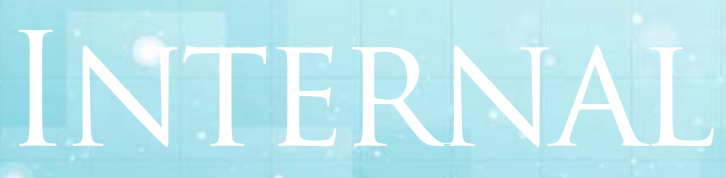

Original papers

also its grade and the extent of its ankle involvement were associated with higher disease activity; on the other hand, the absence of ankle SH was significantly and independently associated with lower disease activity measured by DAS28 $8_{\text {CRP. }}$. The fact that Gutierrez et al. ${ }^{(7)}$ did not observe this evidence could be due to its absence from their study sample, which was more tightly controlled regarding disease activity: compared to our sample, their patients had a lower mean disease duration (3.3 versus 11.2 years) and DAS28 (3.6 versus 4.4, assuming that the authors used ESR to calculate this score), a higher prevalence of CSDMARD ( $95.4 \%$ versus $84.7 \%$ ) and glucocorticoid ( $27.7 \%$ versus $17.5 \%$ ) treatment. This highlights the importance of study population characteristics (Table 1) and their variability: our 183 patients were predominantly women in their $6^{\text {th }}$ decade, with established RA judging by mean disease duration and relatively low frequency of seropositivity. Only to similar populations of RA patients can our results be extrapolated without increasing the risk of improper generalization. Further studies on the subject of clinical and ultrasound ankle involvement could focus on specific RA populations, such as early RA or treatmentnaïve RA, in order to complement and ultimately confirm our observations.

Ankles were excluded from DAS28 for clinicians, but their involvement is ever present in patient's reported outcomes (PtGA). A patient with active inflammation of ankles will give a negative feedback because of pain and gait difficulties even though DAS28 indicates remission. Initially, this clinical reality was acknowledged and Ritchie's 1968 articular index (RAI) evaluated ankles $^{(16)}$.

RAl was then included in Mallya's 1981 index ${ }^{(17)}$, which was first used in a modified form (van Riel's 1984 index) to assess response to treatment in a clinical trial ${ }^{(18)}$. RAI was also included in the first form of DAS $(1990)^{(19)}$ which was validated in 1992 for clinical trials ${ }^{(20)}$.

In 1985, Egger et al. ${ }^{(21)}$ reduced joint counts, but did not exclude ankles, and in 1989 Fuchs et $a l^{(22)}$ proposed the 28 joint count and excluded ankles. Without denying the importance of RA ankle involvement, the authors motivated the exclusion of ankles with two arguments (excess time needed to clinically evaluate these joints and confounding diagnoses which can mimic RA involvement), even though in their study, ankles and wrists had equal Lansbury index weighting and elbows and thumbs were less frequently involved clinically than ankles. Finally, the 28 joint count was used in 1995 to develop and validate the current DAS28 by Prevoo et al. ${ }^{(1)}$. The authors compared the ability of scores with traditional joint counts 

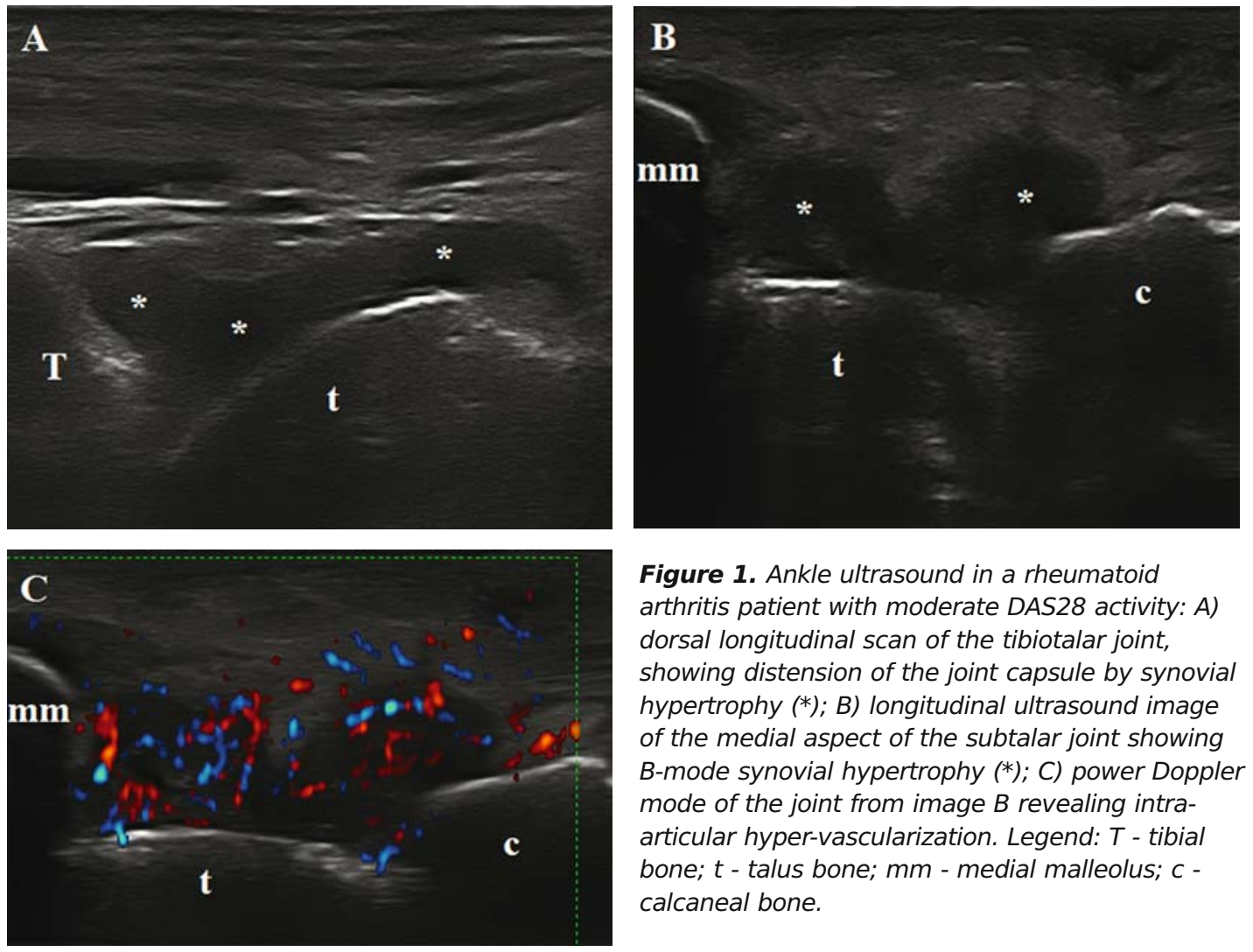

Figure 1. Ankle ultrasound in a rheumatoid arthritis patient with moderate DAS28 activity: A) dorsal longitudinal scan of the tibiotalar joint, showing distension of the joint capsule by synovial hypertrophy (*); B) longitudinal ultrasound image of the medial aspect of the subtalar joint showing $B$-mode synovial hypertrophy (*); C) power Doppler mode of the joint from image $B$ revealing intraarticular hyper-vascularization. Legend: $T$ - tibial bone; $t$ - talus bone; $\mathrm{mm}$ - medial malleolus; $c$ calcaneal bone.

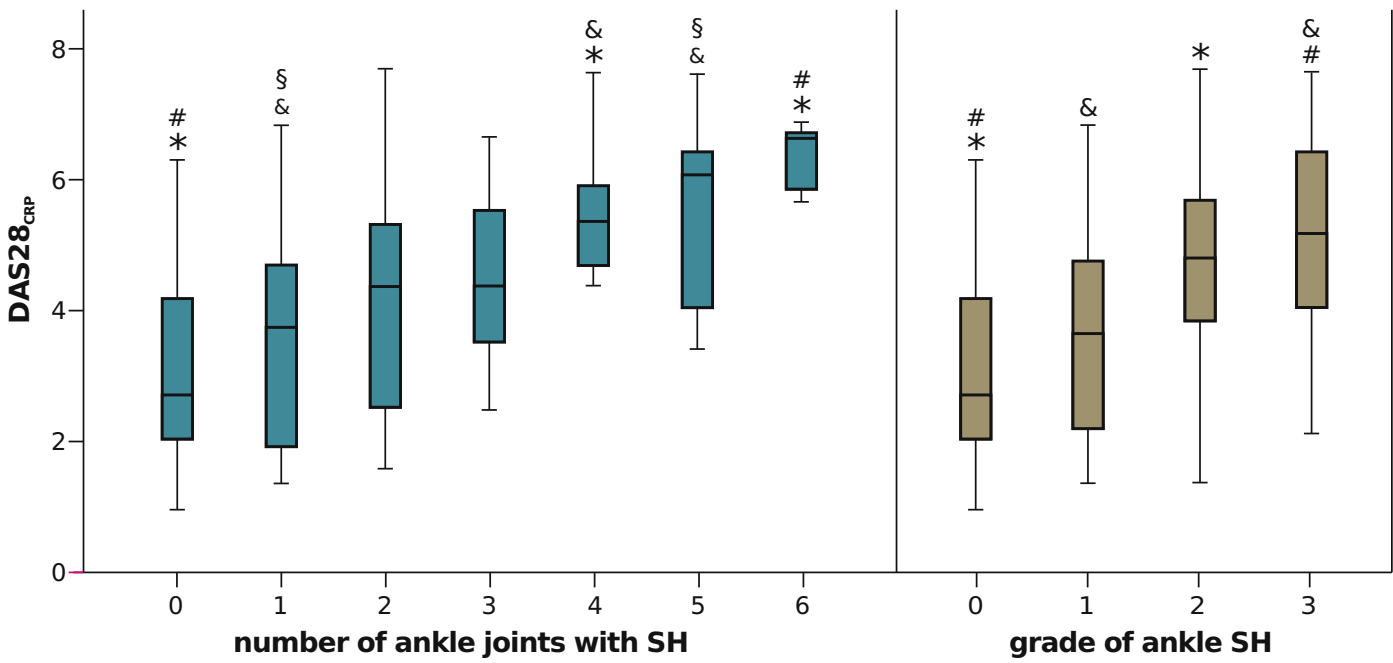

Figure 2. Median DAS28 $8_{C R P}$ according to the number of ankle joints with $\mathrm{SH}$ (left) and the grade of ankle SH (right). Left: categories contain the number of patients with 0 to 6 ankle joints with SH (either left or right TTJS, TNJs and STJS): "O" = 86 patients with no ankle joints with SH; "1" = 28 patients with SH in 1 ankle joint (for example the right TTJ); "2" = 28 patients with SH in 2 ankle joints (for example the right TNJ and left STJ); "3" = 14; "4" = 17; " $5 "=5 ; " ~ 6 "=5$. Kruskal Wallis test $(n=183$; statistic $=46.5,6$ degrees of freedom; $p<0.001$ ) with post-hoc analysis (Bonferoni): * $p<0.001 ; \# p=0.001 ; \& p=0.003 ; \S p=0.011$. Right: Initially, each left and right TTJ, TNJ and STJ was graded individually. Then left and right homologous joints were compared and the highest grade was retained for each joint type (for example, if a

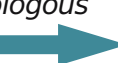


patients had grade $2 \mathrm{SH}$ in the left TTJ and grade $1 \mathrm{SH}$ in the right TTJ, the patient's SH of TTJ was graded with 2). Finally, the highest grade of $\mathrm{SH}$ among joint types defined the patient's general ankle $\mathrm{SH}$ grade (for example, if a patient had grade $2 \mathrm{SH}$ in the TT), grade $1 \mathrm{SH}$ in the TNJ and no SH in the STJ, ankle SH was graded 2). There were 85 (46.4\%) grade 0 patients, 32 (17.5\%) grade 1, 44 (24.1\%) grade 2 and 22 (12.0\%) grade 3. Kruskal Wallis test $(n=183$; statistic $=35.2,3$ degrees of freedom; $p$ $<0.001$ ) with post-hoc analysis (Bonferoni): * \# $p<0.001 ; \& p=0.013$. Abbreviations: CRP - Creactive protein; DAS - disease activity score; SH - synovial hypertrophy; STJ - subtalar joint; TNJ talonavicular joint; TTJ - tibiotalar joint.

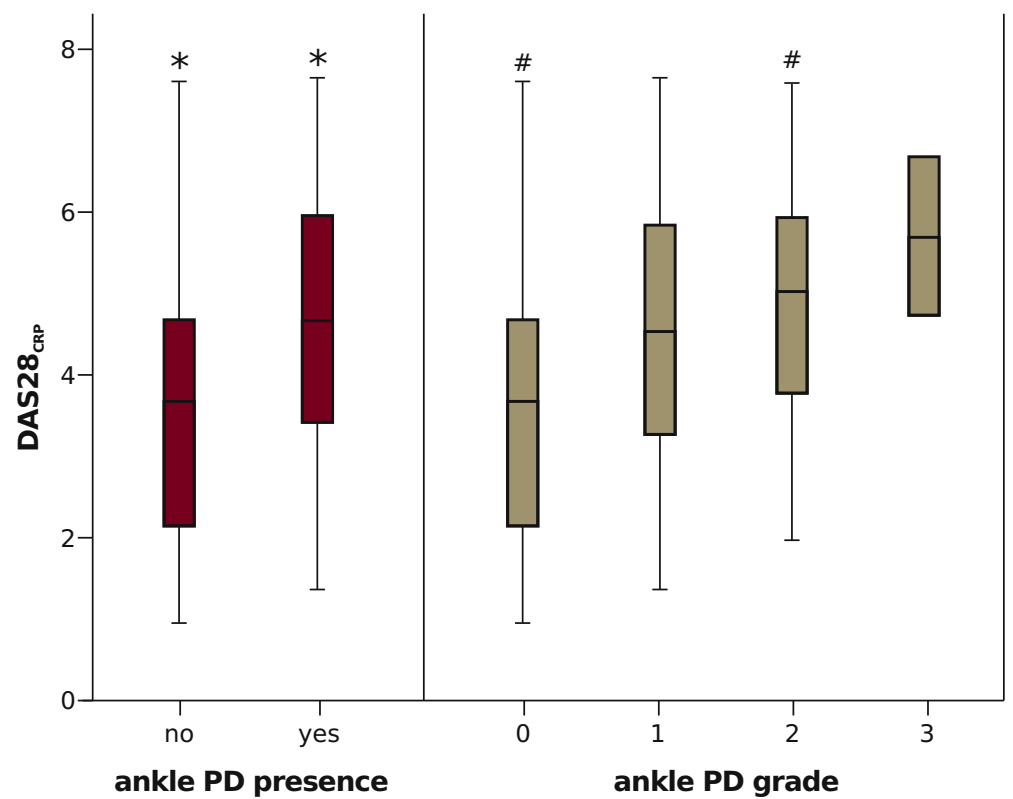

Figure 3. Median DAS28CRP according to PD presence (left) and grade (right). First, for each left and right TTJ, TNJ and STJ the presence and grade of PD were noted. Second, left and right homologous joints were compared and the presence and the highest grade was retained for each joint type (for example, if a patients had grade 2 PD in the left $T T$ J and grade 1 PD in the right TTJ, the patient's PD of TTJ was graded with 2). Third, the presence of $P D$ in any joint type defined ankle PD presence and the highest grade of $P D$ among joint types defined the patient's general ankle $P D$ grade (for example, if a patient had grade $2 P D$ in the TTJ, grade 1 PD in the TNJ and no PD in the STJ, the ankle PD was graded 2). There were 45 (24.6\%) patients with positive PD signal in ankle joints, 138 (75.4\%) grade 0 patients, 28 (15.3\%) grade 1, 15 (8.2\%) grade 2 and 2 (1.1\%) grade 3. Left: Mann Whitney test $(* p<0.001)$. Right: Kruskal Wallis test $(n=$ 183; statistic $=14.1,3$ degrees of freedom; $p=0.003$ ) with post-hoc analysis (Bonferoni): $\# p=0.009$. CRP - C-reactive protein; DAS - disease activity score; PD - power Doppler signal; STJ - subtalar joint; TNJ talonavicular joint; TTJ - tibiotalar joint. 
which included ankles and the ability of scores with 28 joint counts without ankles to discriminate between patients with "low" and "high" disease activity defined by rheumatologists' decision to stop, continue, add or switch csDMARDs. Therefore, DAS28 was developed in the pre-bDMARD and pretsDMARD era, when ultrasound was highly limited (spread, cost, technology, examiner's expertise, evidence-based data) and when regression analysis was slightly different, using highly subjective endpoint definitions of discriminative levels of activity. Probably today's b/tsDMARD-naïve RA patients are the same as 25 years ago when DAS28 appeared, but patients on these drugs, especially those in DAS28-defined remission, can conceal subclinical active synovitis(23), and can progress radiographically ${ }^{(24)}$. This is true not only clinically, but it is reflected RA synovitis histopathology: Orr et al. ${ }^{(9)}$ reported that $49.4 \%$ of patients with normal CRP and $71.4 \%$ of patients with DAS28-defined remission had evidence of synovial inflammation on biopsies.

In our opinion, exclusion of ankles from DAS28 was not thoroughly justified, since they are closely linked to RA activity as our results indicate. Rheumatologists already evaluate ankles in psoriatic arthritis in order to calculate DAPSA ${ }^{(25)}$. For the purpose of RA activity assessment, inspection, palpation and passive and active movement of these relatively large joints could allow the examiner to decide whether to count ankles as tender and/or swollen in less than 2 minutes. Comorbid conditions are an issue for all joint evaluations, for example knee osteoarthritis. Ankles are less prone to develop primary osteoarthritis and more prone to develop secondary osteoarthritis because of trauma and inflammatory rheumatic diseases which should be evident from the patient's medical history. Additionally, ultrasound and general clinical evaluation can exclude non-RA causes of ankle pain/tenderness. In fact, ultrasound has already proved that the absence of PD signals, not DAS28 remission, predicts the lack of radiographic progression ${ }^{(26)}$. In contrast to controlled trials, clinicians are free to diagnose and treat cases of RA which do not fulfil the classification criteria ${ }^{(8)}$ and to adjust RA treatment of patients in DAS28 remission with ankle involvement. Perhaps, a more accurate clinical evaluation of RA activity would be obtained by using a DAS30 (DAS28 with ankles) or the original DAS, in order to increase the possibility to attain true remission in each patient.

Several study limitations should be taken into consideration when assessing the relevance of our results: the cross sectional study design, the lack of an inter-observer study, the fact that clinical examination was not done individually at the level of each ankle structure (joint, tendon) and the fact that bone damage (erosions) was not evaluated either by conventional radiography or ultrasound.

\section{Conclusion}

Clinical ankle involvement and ultrasounddetected ankle $\mathrm{SH}$ have a directly proportional relationship with disease activity in RA. Clinical ankle tenderness was more sensitive to detect ultrasound-defined $\mathrm{SH}$, while swollen ankles were more specific, but the overall predictive capacities of both clinical signs were equivalent. A new DAS is needed, in order to reflect the clinical reality of today's RA patients, a DAS which should include clinical evaluation of ankles and ultrasound information. 


\section{INTERNAL}

\section{Original papers}

\section{Conflicts of interest}

The authors declare that there are not conflicts of interest.

\section{References}

1. Prevoo ML, van 't Hof MA, Kuper HH, van Leeuwen MA, van de Putte $L B$, van Riel PL. Modified disease activity scores that include twenty-eight-joint counts. Development and validation in a prospective longitudinal study of patients with rheumatoid arthritis. Arthritis Rheum. 1995;38(1):44-8.

2. Yano $K$, Ikari $K$, Inoue $E$, Sakuma $Y$, Mochizuki $T$, Koenuma $N$, et al. Features of patients with rheumatoid arthritis whose debut joint is a foot or ankle joint: A 5,479case study from the IORRA cohort. PLoS One. 2018;13(9):e0202427.

3. van TuyI LH, Britsemmer K, Wells GA, SmolenJS, Zhang $B$, Funovits J, et al. Remission in early rheumatoid arthritis defined by 28 joint counts: limited consequences of residual disease activity in the forefeet on outcome. Ann Rheum Dis. 2012;71(1):33-7.

4. Toyota Y, Tamura M, Kirino Y, Sugiyama Y, Tsuchida N, Kunishita $Y$, et al. Musculoskeletal ultrasonography delineates ankle symptoms in rheumatoid arthritis. Mod Rheumatol. 2017;27(3):425-9.

5. Hennessy K, Woodburn J, Steultjens M. Clinical practice guidelines for the foot and ankle in rheumatoid arthritis: a critical appraisal. J Foot Ankle Res. 2016;9:31.

6. Elsaman AM, Mostafa ES, Radwan AR. Ankle Evaluation in Active Rheumatoid Arthritis by Ultrasound: A Cross-Sectional Study. Ultrasound Med Biol. 2017;43(12):2806-13.

7. Gutierrez M, Pineda C, Salaffi F, Raffeiner B, Cazenave $T$, Martinez-Nava GA, et al. Is ankle involvement underestimated in rheumatoid arthritis? Results of a multicenter ultrasound study. Clin Rheumatol. 2016;35(11):2669-78.

8. Aletaha $D$, Neogi $T$, Silman AJ, Funovits J, Felson DT, Bingham CO, 3rd, et al. 2010 rheumatoid arthritis classification criteria: an American College of
Rheumatology/European League Against Rheumatism collaborative initiative. Ann Rheum Dis. 2010;69(9):1580-8.

9. Orr CK, Najm A, Young F, McGarry T, Biniecka M, Fearon $U$, et al. The Utility and Limitations of CRP, ESR and DAS28-CRP in Appraising Disease Activity in Rheumatoid Arthritis. Front Med (Lausanne). 2018;5:185.

10. Smolen JS, Breedveld FC, SchiffMH, Kalden JR, Emery $P$, Eberl G, et al. $\underline{A}$ simplified disease activity index for rheumatoid arthritis for use in clinical practice. Rheumatology (Oxford). 2003;42(2):244-57.

11. Naredo E, D'Agostino MA, Wakefield RJ, Moller I, Balint PV, Filippucci E, et al. Reliability of a consensusbased ultrasound score for tenosynovitis in rheumatoid arthritis. Ann Rheum Dis. 2013;72(8):1328-34.

12. Wakefield RJ, Balint PV, Szkudlarek M, Filippucci E, Backhaus M, D'Agostino MA, et al. Musculoskeletal ultrasound including definitions for ultrasonographic pathology.J Rheumatol. 2005;32(12):2485-7.

13. Szkudlarek M, Court-Payen M, Jacobsen S, Klarlund M, Thomsen HS, Ostergaard M. Interobserver agreement in ultrasonography of the finger and toe joints in rheumatoid arthritis. Arthritis Rheum. 2003;48(4):955-62.

14. Szkudlarek M, Court-Payen M, Strandberg C, Klarlund M, Klausen T, Ostergaard M. Power Doppler ultrasonography for assessment of synovitis in the metacarpophalangeal joints of patients with rheumatoid arthritis: a comparison with dynamic magnetic resonance imaging. Arthritis Rheum. 2001;44(9):2018-23.

15. Terslev L, Naredo E, Aegerter P, Wakefield RJ, Backhaus $M$, Balint $P$, et al. Scoring ultrasound synovitis in rheumatoid arthritis: a EULAR-OMERACT ultrasound taskforce-Part 2: reliability and application to multiple joints of a standardised consensus-based scoring system. RMD Open. 2017;3(1):e000427.

16. Ritchie DM, Boyle JA, Mclnnes JM, Jasani MK, Dalakos $T G$, Grieveson $P$, et al. Clinical studies with an articular index for the assessment of joint tenderness in patients with rheumatoid arthritis. Q J Med. 1968;37(147):393406.

17. Mallya RK, Mace BE. The assessment of disease 
activity in rheumatoid arthritis using a multivariate analysis. Rheumatol Rehabil. 1981;20(1):14-7.

18. van Riel PL, van de Putte $L B$, Gribnau FW, Macrae $K D$. Comparison of auranofin and aurothioglucose in the treatment of rheumatoid arthritis: a single blind study. Clin Rheumatol. 1984;3 Suppl 1:51-6.

19. van der Heijde $D M$, van 't Hof $M A$, van Riel $P L$, Theunisse LA, Lubberts EW, van Leeuwen MA, et al. Judging disease activity in clinical practice in rheumatoid arthritis: first step in the development of a disease activity score. Ann Rheum Dis. 1990;49(11):916-20.

20. van der Heijde $D M$, van't Hof $M A$, van Riel $P L$, van Leeuwen MA, van Rijswijk $M H$, van de Putte $L B$. Validity of single variables and composite indices for measuring disease activity in rheumatoid arthritis. Ann Rheum Dis. 1992;51(2):177-81.

21. Egger MJ, Huth DA, Ward JR, Reading JC, Williams HJ. Reduced joint count indices in the evaluation of rheumatoid arthritis. Arthritis Rheum. 1985;28(6):613-9. 22. Fuchs $H A$, Brooks $R H$, Callahan $L F$, Pincus T. $A$ simplified twenty-eight-joint quantitative articular index in rheumatoid arthritis. Arthritis Rheum.
1989;32(5):531-7.

23. Cruces $M, A$ I Snih S, Serra-Bonett $N$, Rivas JC. Subclinical Synovitis Measured by Ultrasound in Rheumatoid Arthritis Patients With Clinical Remission Induced by Synthetic and Biological Modifying Disease Drugs. Reumatol Clin. 2017.

24. Sewerin $P$, Vordenbaeumen $S$, Hoyer A, Brinks $R$, Buchbender $C$, Miese $F$, et al. Silent progression in patients with rheumatoid arthritis: is DAS28 remission an insufficient goal in RA? Results from the German Remission-plus cohort. BMC Musculoskelet Disord. 2017;18(1):163.

25. Schoels M, Aletaha D, Funovits J, Kavanaugh A, Baker $D$, Smolen JS. Application of the DAREA/DAPSA score for assessment of disease activity in psoriatic arthritis. Ann Rheum Dis. 2010;69(8):1441-7.

26. de Miguel E, Pecondon-Espanol A, Castano-Sanchez M, Corrales A, Gutierrez-Polo R, Rodriguez-Gomez M, et al. A reduced 12-joint ultrasound examination predicts lack of X-ray progression better than clinical remission criteria in patients with rheumatoid arthritis. Rheumatol Int. 2017;37(8):1347-56. 